\title{
The management of Skin Toxicity Associated with Vemurafenib in Metastatic Malignant Melanoma
}

\section{Metastatik Malign Melanomda Vemurafenib İlişkili Cilt Toksisitesi}

\author{
Fatih Yıldız ${ }^{1}$, Bengü Nisa Akay ${ }^{2}$, Umut Demirci ${ }^{1}$ \\ ${ }^{1}$ Dr. A. Y. Ankara Onkoloji Eğitim Ve Araştırma Hastanesi, Tıbbi Onkoloji Kliniği, Ankara, Türkiye \\ ${ }^{2}$ Ankara Üniversitesi Tip Fakültesi, Dermatoloji Anabilim Dalı, Ankara, Türkiye
}

Dergiye ulaşma tarihi:25/08/2014, Dergiye kabul tarihi:08/09/2014, Doi: 10.5505/aot.2014.14633

Anahtar Kelimeler: Cilt toksisitesi; Malign melanom; Vemurafenib

Key words: Skin toxicity; Malignant melanoma; Vemurafenib

\section{Sayın Editör,}

Malign melanomların (MM) \%40-60'1 BRAF mutasyonu taşır. Vemurafenib ve dabrafenib V600E ve V600K mutasyonu taşıyan metastatik MM'de genel sağkalım katkısı gösterilmiş ajanlardır $(1,2)$. Bununla birlikte diğer hedefe yönelik tedavilerde olduğu gibi vemurafenib kullanımında da çok sayıda cilt toksisitesi görülebilmektedir $(3,4)$. Kutanöz yan etkiler vemurafenib tedavisinde nadiren kalıc1 tedavi kesilmesini gerektiren, doz modifikasyonu ve destekleyici tedavi ile genellikle yönetilebilir bir durumdur. Burada metastatik MM tanılı bir hastada vemurafenibe bağlı gelişen yaygın makulopapüler döküntü ve bu yan etkinin yönetimini vurguladık.

Kırkaltı yaşında erkek hasta, 23 ay önce sol el dorsal yüzde ortaya çıkan kitle lezyonu eksizyonu sonucu Evre 2B MM tanısıyla tedavisiz izleme alındı. Onsekiz ay sonra sol epitroklear bölgede ve akciğerde metastaz saptanması üzerine temozolamid tedavisi başlandı. Üç aylık temozolamid tedavisi sonrasi akciğerdeki metastatik lezyonlarda progresyon izlendi. BRAF V600E mutasyonu tesbit edilmesi üzerine hastaya vemurafenib 2 × $960 \mathrm{mg} /$ gün tedavisi başland. Tedavinin 10. gününde hasta vücudunun \%50'sinden daha fazlasını kaplayan kaşıntılı makülopapüler cilt döküntüsü (grad 3) ile başvurdu (Resim 1a). Vemurafenib dozu \%50 azaltılarak 2 x $480 \mathrm{mg}$ /güne düşüldü ve hastaya $0.5 \mathrm{mg} / \mathrm{kg}$ prednizolon ve $5 \mathrm{mg}$ desloratadin başlandı. İzlemde kaşıntısı azalan hastanın 7 gün sonra makülopapüler cilt döküntüsü tamamen kayboldu (Resim 1b).

Prednizolon azalt1larak kesilirken desloratadine devam edildi, vemurafenib dozu tekrar 2x960 mg'a yükseltildi. Ondördüncü gün kontrolünde ilaç ilişkili cilt lezyonu olmayan hastanın halen tedavisine devam edilmektedir.

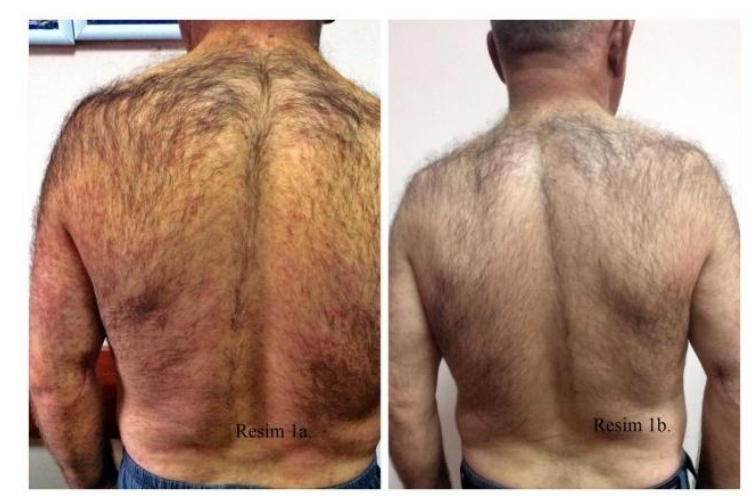

Resim 1: a. Makülopapüler cilt döküntüsü b. Cilt döküntüsünün tamamen gerilemiş hali.

Vemurafenib kullanımına bağlı en sık görülen cilt yan etkisi hastaların \%64-75'inde görülen raş iken, makülopapüler raş \%4-21 hastada bildirilmiştir (1-4). Vemurafenibe bağlı grad 1-2 maküler raş gelişmesi durumunda ilacın ayn dozda devam edilmesi ve ek olarak topikal steroid, oral antihistaminik ve $0.5 \mathrm{mg} / \mathrm{kg}$ 'dan oral steroid kullanılmas1, grad 3 toksisite durumundaysa ilacin kesilmesi ya da doz modifikasyonu önerilmektedir (5).

Bununla birlikte hedefe yönelik tedavi kullanan hastalarda tedaviye ara verilmesinin ilaç direnci ile ilişkili olabileceği gözönüne alınarak bu hastaların cilt toksisitelerinin tıbbi onkoloji ve deneyimli dermatoloji klinikleri ile beraber multidisipliner takibi ve yönetimi 
önemlidir.

\section{Çıkar Çatışması: Yok}

\section{Referanslar}

1. Hauschild A, Grob JJ, Demidov LV, et al. Dabrafenib in BRAF-mutated metastatic melanoma: a multicentre, open-label, phase 3 randomised controlled trial Lancet. 2012;380:358-65

2. McArthur GA, Chapman PB, Robert C, et al. Safety and efficacy of vemurafenib in BRAF(V600E) and BRAF(V600K) mutation-positive melanoma (BRIM-
3): extended follow-up of a phase 3, randomised, open-label study. Lancet Oncol 2014;15:323-32

3. Sinha R, Edmonds K, Newton-Bishop JA, et al. Cutaneous adverse events associated with vemurafenib in patients with metastatic melanoma: practical advice on diagnosis, prevention and management of the main treatment-related skin toxicities, Br J Dermatol 2012;167:987-94

4. Boussemart L, Routier E, Mateus C, et al. Prospective study of cutaneous side-effects associated with the BRAF inhibitor vemurafenib: a study of 42 patients, Ann Oncol 2013;24:1691-7

5. Lacouture ME, Duvic M, Hauschild A, et al. Analysis of Dermatologic Events in Vemurafenib-Treated Patients With Melanoma. The Oncologist 2013;18:314-22 